\title{
Effects of Abscisic Acid (ABA) on Growth of Cosmos sulphureus
}

Qian Zhang ${ }^{1, a}$, Huashan Lian ${ }^{2, b}$, Xun Wang ${ }^{3, c}$, Wei Jiang ${ }^{4, d}$ and Lijin Lin ${ }^{3, e^{*}}$

${ }^{1}$ College of Horticulture, Sichuan Agricultural University, Chengdu, Sichuan, China

${ }^{2}$ Subcollege of Garden and Horticulture, Chendu Agricultural College, Chengdu, Sichuan, China

${ }^{3}$ Institute of Pomology and Olericulture, Sichuan Agricultural University, Chengdu, Sichuan, China

${ }^{4}$ College of Chemistry and Life Science, Chengdu Normal University, Chengdu, Sichuan, China

a1964292607@qq.com, ㅎ49939450@qq.com, 35744023@qq.com, d1399945180@qq.com, ellj800924@163.com

${ }^{*}$ Corresponding author. Qian Zhang, Huashan Lian and Xun Wang contributed equally to this work.

Keywords: Abscisic acid; Cosmos sulphureus; Growth; Physiology

Abstract: A pot experiment was carried out to investigate the effects of applying abscisic acid (ABA) on growth and physiology of Cosmos sulphureus. The results showed that application of ABA promoted the growth of $C$. sulphureus. ABA increased the biomass and photosynthetic pigment content of $C$. sulphureus. With the increase of ABA concentrations, the biomass and photosynthetic pigment content of $C$. sulphureus increased when the dose of ABA was not more than $5 \mathrm{mg} / \mathrm{L}$, and decreased when the dose of ABA was higher than $5 \mathrm{mg} / \mathrm{L}$. The application of ABA increased the soluble sugar contents in roots and shoots of $C$. sulphureus, and had the increasing trend with the increase of $\mathrm{ABA}$ concentrations. With the increase of ABA concentrations, the CAT activity and the soluble sugar content of $C$. sulphureus increased. All concentrations of ABA improved the POD activity, and only 5 and $10 \mathrm{mg} / \mathrm{L} \mathrm{ABA}$ improved the SOD activity. Therefore, application of ABA could promote the growth of $C$. sulphureus.

\section{Introduction}

Abscisic acid (ABA) is an important plant hormone that regulates plant growth and development, participates in stress signal transduction, and improves plants' resistance to various stresses [1-3]. ABA can promote stomata closure and induce resistance protein synthesis through signal transduction of the defense cell membrane to enhance the resist ability of plant to stress, and also can regulate the expression of genes and proteins [3]. When growing in stress environment, the contents of ABA in plant tissues increase to regulate the physiology of plants [4-5]. Under low temperature stress, ABA effectively increases the SOD activity of banana seedlings, and reduces the relative conductivity of banana seedling leaves [6]. ABA also reduces the respiration rate of leaves of sweet pepper seedlings under low temperature stress [7]. ABA promotes the accumulation of photosynthetic products in leaves, and affects the activity of key enzymes in anthocyanin synthesis and the content of some intermediates, indicating that ABA may play a role in the process of peach dyeing [8]. The ABA content in roots of cucumber seedlings was shown to increase with increasing lead concentrations [9], and different concentrations of cadmium were shown to stimulate ABA synthesis in roots of soybean seedling [10].

Cosmos sulphureus is one of annual herbaceous floricultural plants, origining from in Mexico [11]. In this study, we used the different concentrations of ABA to treat $C$. sulphureus, and studied the effects of ABA on growth and physiology of $C$. sulphureus. The aim of the study was to screen the best ABA concentration which could promote the growth of $C$. sulphureus, and provided a reference for applying the plant hormones on other floricultural plants. 


\section{Materials and Methods}

Experimental Design. The nutrient soils and pearlites $(2: 1)$ were put into polyethylene pot (15 $\mathrm{cm}$ high, $18 \mathrm{~cm}$ in diameter). Three uniform C. sulphureus seedlings with four euphyllas were transplanted into each pot in April 2016. When the plants grew to 10 euphyllas, 5 concentrations $(0,5,10,15$ and 20 $\mathrm{mg} / \mathrm{L}$ ) of ABA with 3 replicates were sprayed on the leaves of plants, respectively. Each treatment was repeated three times with a $10-\mathrm{cm}$ spacing between pots. The soil moisture content was maintained at $80 \%$ of field capacity until the plants were harvested. At 60 days after planting (July 2016), the plants were harvested. The upper mature leaves of plants were collected to determine the photosynthetic pigment (chlorophyll $a$, chlorophyll $b$ and total chlorophyll) contents [12]. The upper young leaves (2 $\mathrm{cm}$ in length) were collected to determine the superoxide dismutase (SOD) activity, peroxidase (POD) activity, catalase (CAT) activity and soluble protein content [12]. Then, the whole plants were then gently removed, the roots, stems and leaves were washed with tap water followed by deionized water, and the biomasses of root, stem and leaf were measured. The soluble sugar contents in roots, stems and leaves were determined by the anthrone colorimetry with dry weight plant samples [12].

Experimental Design. Statistical analyses were conducted using SPSS 13.0 statistical software (IBM, Chicago, IL, USA). Data were analyzed by one-way analysis of variance with least significant difference (LSD) at the $\mathrm{p}=0.05$ confidence level.

\section{Results and Discussion}

Biomass of $\boldsymbol{C}$. sulphureus. With the increase of ABA concentrations, the root, stem, leaf and shoot biomasses of $C$. sulphureus increased when the dose of ABA was not more than $5 \mathrm{mg} / \mathrm{L}$, and decreased when the dose of ABA was higher than $5 \mathrm{mg} / \mathrm{L}$ (Table 1). The order of root, stem, leaf and shoot biomasses of $C$. sulphureus were $5 \mathrm{mg} / \mathrm{L}$ ABA $>10 \mathrm{mg} / \mathrm{L} \mathrm{ABA}>15 \mathrm{mg} / \mathrm{L}$ ABA $>20 \mathrm{mg} / \mathrm{L}$ ABA $>0$ $\mathrm{mg} / \mathrm{L}$ ABA. When the dose of ABA was $5,10,15$ and $20 \mathrm{mg} / \mathrm{L}$, the root biomass increased by $13.83 \%$ $(P<0.05), 9.22 \%(P>0.05), 5.32 \%(P>0.05)$ and $1.77 \%(P>0.05)$ respectively compared with the control, and the shoot biomass increased by $28.69 \%(P<0.05), 20.02 \%(P<0.05), 15.02 \%(P<0.05)$ and $7.08 \%(P>0.05)$ respectively. So, in this experiment, ABA could promote the growth of $C$. sulphureus, and the best dose was $5 \mathrm{mg} / \mathrm{L} \mathrm{ABA}$.

Table 1 Biomass of C. sulphureus

\begin{tabular}{|c|c|c|c|c|}
\hline $\begin{array}{c}\text { Treatments } \\
(\mathrm{mg} / \mathrm{L})\end{array}$ & $\begin{array}{c}\text { Root biomass } \\
(\mathrm{g} / \mathrm{plant})\end{array}$ & $\begin{array}{c}\text { Stem biomass } \\
(\mathrm{g} / \text { plant })\end{array}$ & $\begin{array}{c}\text { leaf biomass } \\
(\mathrm{g} / \mathrm{plant})\end{array}$ & $\begin{array}{c}\text { Shoot biomass } \\
(\mathrm{g} / \mathrm{plant})\end{array}$ \\
\hline 0 & $2.82 \pm 0.155 \mathrm{~b}$ & $5.20 \pm 0.156 \mathrm{c}$ & $2.99 \pm 0.145 \mathrm{c}$ & $8.19 \pm 0.300 \mathrm{~d}$ \\
\hline 5 & $3.21 \pm 0.063 \mathrm{a}$ & $6.57 \pm 0.217 \mathrm{a}$ & $3.97 \pm 0.155 \mathrm{a}$ & $10.54 \pm 0.061 \mathrm{a}$ \\
\hline 10 & $3.08 \pm 0.122 \mathrm{ab}$ & $5.99 \pm 0.092 \mathrm{bc}$ & $3.84 \pm 0.147 \mathrm{bc}$ & $9.83 \pm 0.055 \mathrm{~b}$ \\
\hline 15 & $2.97 \pm 0.075 \mathrm{ab}$ & $5.90 \pm 0.190 \mathrm{bc}$ & $3.52 \pm 0.199 \mathrm{bc}$ & $9.42 \pm 0.009 \mathrm{c}$ \\
\hline 20 & $2.87 \pm 0.084 \mathrm{~b}$ & $5.61 \pm 0.134 \mathrm{c}$ & $3.16 \pm 0.163 \mathrm{c}$ & $8.77 \pm 0.296 \mathrm{~d}$ \\
\hline
\end{tabular}

Photosynthetic pigment content in $\boldsymbol{C}$. sulphureus. The same as the biomass, the chlorophyll a, chlorophyll b, total chlorophyll and carotenoid contents of $C$. sulphureus increased when the dose of ABA was not more than $5 \mathrm{mg} / \mathrm{L}$, and decreased when the dose of ABA was higher than $5 \mathrm{mg} / \mathrm{L}$ (Table 2). The contents of chlorophyll a, chlorophyll $b$, total chlorophyll and carotenoid reached the maxmium when the dose of ABA was $5 \mathrm{mg} / \mathrm{L}$. When the dose of ABA was $5,10,15$ and $20 \mathrm{mg} / \mathrm{L}$, the contents of chlorophyll a, chlorophyll b, total chlorophyll and carotenoid increased. When the dose of ABA was 5, 10,15 and $20 \mathrm{mg} / \mathrm{L}$, the total chlorophyll content increased by $8.16 \%(P>0.05), 6.41 \%(P>0.05)$, 5.63\% $(P>0.05)$ and $1.36 \%(P>0.05)$ respectively compared with the control, and the content of carotenoid increased by $8.62 \%(P>0.05), 7.14 \%(P>0.05), 6.40 \%(P>0.05)$ and $1.48 \%(P>0.05)$ respectively. So, ABA could improve the photosynthesis of $C$. Sulphureus, and the best dose was 5 $\mathrm{mg} / \mathrm{L}$ ABA. 
Table 2 Photosynthetic pigment content of C. sulphureus

\begin{tabular}{|c|c|c|c|c|}
\hline $\begin{array}{c}\text { Treatments } \\
(\mathrm{mg} / \mathrm{L})\end{array}$ & $\begin{array}{c}\text { Chlorophyll a } \\
(\mathrm{mg} / \mathrm{g})\end{array}$ & $\begin{array}{c}\text { Chlorophyll b } \\
(\mathrm{mg} / \mathrm{g})\end{array}$ & $\begin{array}{c}\text { Total chlorophyll } \\
(\mathrm{mg} / \mathrm{g})\end{array}$ & $\begin{array}{c}\text { Carotenoid } \\
(\mathrm{mg} / \mathrm{g})\end{array}$ \\
\hline 0 & $1.186 \pm 0.018 \mathrm{a}$ & $0.359 \pm 0.003 \mathrm{~b}$ & $1.545 \pm 0.021 \mathrm{~b}$ & $0.406 \pm 0.008 \mathrm{~b}$ \\
\hline 5 & $1.275 \pm 0.027 \mathrm{a}$ & $0.396 \pm 0.009 \mathrm{a}$ & $1.671 \pm 0.036 \mathrm{ab}$ & $0.441 \pm 0.012 \mathrm{a}$ \\
\hline 10 & $1.259 \pm 0.031 \mathrm{a}$ & $0.385 \pm 0.006 \mathrm{ab}$ & $1.644 \pm 0.037 \mathrm{ab}$ & $0.435 \pm 0.006 \mathrm{ab}$ \\
\hline 15 & $1.251 \pm 0.063 \mathrm{a}$ & $0.381 \pm 0.016 \mathrm{ab}$ & $1.632 \pm 0.079 \mathrm{ab}$ & $0.432 \pm 0.016 \mathrm{ab}$ \\
\hline 20 & $1.200 \pm 0.033 \mathrm{a}$ & $0.366 \pm 0.010 \mathrm{ab}$ & $1.566 \pm 0.043 \mathrm{ab}$ & $0.412 \pm 0.012 \mathrm{~b}$ \\
\hline
\end{tabular}

Soluble sugar content in $\boldsymbol{C}$. sulphureus. The application of ABA increased the soluble sugar contents in roots and stems of $C$. sulphureus (Table 3 ). With the increase of ABA concentrations, the soluble sugar contents in roots and stems of $C$. sulphureus had the increasing trend. The order of the soluble sugar contents in roots and stems of $C$. sulphureus were $20 \mathrm{mg} / \mathrm{L} \mathrm{ABA}>15 \mathrm{mg} / \mathrm{L} \mathrm{ABA}>10$ $\mathrm{mg} / \mathrm{L} \mathrm{ABA}>5 \mathrm{mg} / \mathrm{L} \mathrm{ABA}>0 \mathrm{mg} / \mathrm{L} \mathrm{ABA}$. When the dose of ABA was $5,10,15$ and $20 \mathrm{mg} / \mathrm{L}$, the soluble sugar contents in roots increased by $12.01 \%(P<0.05), 32.25 \%(P<0.05), 34.51 \%(P<0.05)$ and $38.21 \%(P<0.05)$ respectively compared with the control, and the soluble sugar contents in stems increased by $14.54 \%(P<0.05), 16.95 \%(P<0.05), 18.78 \%(P<0.05)$ and $22.05 \%(P<0.05)$ respectively. However, the application of ABA decreased the soluble sugar contents in leaves of $C$. sulphureus (Table 3). When the dose of ABA was 5, 10, 15 and $20 \mathrm{mg} / \mathrm{L}$, the soluble sugar contents in leaves decreased by $19.17 \%(P<0.05), 20.18 \%(P<0.05), 29.99 \%(P<0.05)$ and $39.23 \%(P<0.05)$ respectively compared with the control. The application of ABA increased the soluble sugar contents in shoots of $C$. sulphureus (Table 3). When the dose of ABA was 5, 10, 15 and $20 \mathrm{mg} / \mathrm{L}$, the soluble sugar contents in shoots increased by 6.70\% $(P<0.05), 6.94 \%(P<0.05), 8.16 \%(P<0.05)$ and $10.53 \%(P<0.05)$ respectively compared with the control. Therefore, ABA redistributed the soluble sugar in different organs of $C$. sulphureus.

Table 3 Soluble sugar content of C. sulphureus

\begin{tabular}{|c|c|c|c|c|}
\hline $\begin{array}{c}\text { Treatments } \\
(\mathrm{mg} / \mathrm{L})\end{array}$ & $\begin{array}{c}\text { Roots } \\
(\mathrm{mg} / \mathrm{g})\end{array}$ & $\begin{array}{c}\text { Stems } \\
(\mathrm{mg} / \mathrm{g})\end{array}$ & $\begin{array}{c}\text { leaves } \\
(\mathrm{mg} / \mathrm{g})\end{array}$ & $\begin{array}{c}\text { Shoots } \\
(\mathrm{mg} / \mathrm{g})\end{array}$ \\
\hline 0 & $11.07 \pm 0.308 \mathrm{~d}$ & $20.77 \pm 0.612 \mathrm{c}$ & $8.87 \pm 0.111 \mathrm{a}$ & $16.43 \pm 0.378 \mathrm{~b}$ \\
\hline 5 & $12.40 \pm 0.173 \mathrm{c}$ & $23.79 \pm 0.087 \mathrm{~b}$ & $7.17 \pm 0.055 \mathrm{~b}$ & $17.53 \pm 0.356 \mathrm{a}$ \\
\hline 10 & $14.64 \pm 0.188 \mathrm{~b}$ & $24.29 \pm 0.365 \mathrm{~b}$ & $7.08 \pm 0.007 \mathrm{~b}$ & $17.57 \pm 0.446 \mathrm{a}$ \\
\hline 15 & $14.89 \pm 0.267 \mathrm{ab}$ & $24.67 \pm 0.100 \mathrm{ab}$ & $6.21 \pm 0.004 \mathrm{c}$ & $17.77 \pm 0.445 \mathrm{a}$ \\
\hline 20 & $15.3 \pm 0.062 \mathrm{a}$ & $25.35 \pm 0.156 \mathrm{a}$ & $5.39 \pm 0.062 \mathrm{~d}$ & $18.16 \pm 0.050 \mathrm{a}$ \\
\hline
\end{tabular}

Antioxidant enzyme activity of $\boldsymbol{C}$. sulphureus. The application of ABA increased the soluble protein content of $C$. sulphureus (Table 4). With the increase of ABA concentrations, the soluble protein content of $C$. sulphureus had the increasing trend when the dose of ABA was not more than 10 $\mathrm{mg} / \mathrm{L}$, and had the decreasing when the dose of ABA was higher than $10 \mathrm{mg} / \mathrm{L}$. When the dose of ABA was $5 \mathrm{mg} / \mathrm{L}$, the activity of SOD improved, and 10, 15 and $20 \mathrm{mg} / \mathrm{L}$ ABA reduced that (Table 4). The application of ABA improved the activies of POD and CAT (Table 4). When the dose of ABA was 5, 10,15 and $20 \mathrm{mg} / \mathrm{L}$, the activity of POD improved by $35.79 \%(P<0.05), 18.17 \%(P<0.05), 11.77 \%$ $(P<0.05)$ and $3.06 \%(P>0.05)$ respectively compared with the control, and the activity of CAT improved by $66.67 \%(P<0.05), 47.62 \%(P<0.05), 16.67 \%(P>0.05)$ and $9.52 \%(P>0.05)$ respectively.

\section{Conclusions}

The application of ABA promoted the growth of $C$. sulphureus. ABA increased the biomass and photosynthetic pigment content of $C$. sulphureus. With the increase of ABA concentrations, the biomass and photosynthetic pigment content of $C$. sulphureus increased when the dose of ABA was 
not more than $5 \mathrm{mg} / \mathrm{L}$, and decreased when the dose of ABA was higher than $5 \mathrm{mg} / \mathrm{L}$. The application of ABA increased the soluble sugar contents in roots and shoots of $C$. sulphureus, and had the increasing trend with the increase of ABA concentrations. With the increase of ABA concentrations, the CAT activity and the soluble sugar content of $C$. sulphureus increased. All concentrations of ABA improved the POD activity, and only 5 and $10 \mathrm{mg} / \mathrm{L} \mathrm{ABA}$ improved the SOD activity. Therefore, application of ABA could promote the growth of $C$. sulphureus.

Table 4 Antioxidant enzyme activities of $C$. sulphureus

\begin{tabular}{|c|c|c|c|c|}
\hline $\begin{array}{c}\text { Treatments } \\
(\mathrm{mg} / \mathrm{L})\end{array}$ & $\begin{array}{c}\text { Soluble protein content } \\
(\mathrm{mg} / \mathrm{g})\end{array}$ & $\begin{array}{c}\text { SOD activity } \\
(\mathrm{U} / \mathrm{g})\end{array}$ & $\begin{array}{c}\text { POD activity } \\
(\mathrm{U} / \mathrm{g})\end{array}$ & $\begin{array}{c}\text { CAT activity } \\
{[\mathrm{mg} /(\mathrm{g} \cdot \mathrm{min})}\end{array}$ \\
\hline 0 & $4.47 \pm 0.126 \mathrm{c}$ & $246.32 \pm 0.248 \mathrm{~b}$ & $972.70 \pm 7.018 \mathrm{~d}$ & $0.042 \pm 0.002 \mathrm{~b}$ \\
\hline 5 & $4.81 \pm 0.083 \mathrm{c}$ & $258.89 \pm 1.157 \mathrm{a}$ & $1320.81 \pm 21.091 \mathrm{a}$ & $0.070 \pm 0.005 \mathrm{a}$ \\
\hline 10 & $6.06 \pm 0.078 \mathrm{a}$ & $224.64 \pm 0.577 \mathrm{c}$ & $1149.43 \pm 38.363 \mathrm{~b}$ & $0.062 \pm 0.009 \mathrm{a}$ \\
\hline 15 & $5.28 \pm 0.215 \mathrm{~b}$ & $191.55 \pm 3.952 \mathrm{~d}$ & $1087.19 \pm 24.354 \mathrm{c}$ & $0.049 \pm 0.003 \mathrm{~b}$ \\
\hline 20 & $5.21 \pm 0.132 \mathrm{~b}$ & $172.59 \pm 7.333 \mathrm{e}$ & $1002.48 \pm 10.502 \mathrm{~d}$ & $0.046 \pm 0.002 \mathrm{~b}$ \\
\hline
\end{tabular}

\section{Acknowledgements}

This work was financially supported by the 2016 Innovation Training Program of University Student (201610626032) and the Application Infrastructure Project of Science and Technology Department of Sichuan Province (2016JY0258).

\section{References}

[1] K. Ikegami, M. Okamoto, M. Seo and T. Koshiba: Journal of Plant Research Vol. 122 (2009), p. 235.

[2] J.H. Zhang, W.S. Jia, J.C. Yang and A.M. Ismail: Field Crops Research Vol. 97 (2006), p. 111.

[3] B.A.T. Adie, J. Pérez-Pérez, M.M. Pérez-Pérez, M. Godoy, J.J. Sánchez-Serrano, E.A. Schmelz, and R. Solano: Plant Cell Vol. 19 (2007), p. 1665.

[4] H.Q. Yang and Y.L. Jie: Journal of Huazhong Agricultural University Vol. 20 (2001), p. 92.

[5] H.J. Liu, Y. Liu and L.Liu: Biotechnology Bulletin Vol. 24 (2008), p. 7.

[6] R. Fang, X. Long, B. Deng, J. Zhang, J. Tang, W.X. Huang, W.Z. Tang, H.M. Huang and J.Y. Yao: Hubei Agricultural Sciences Vol. 59 (2014), p. 4879.

[7] L.J. Luo, F.L. Xu, H.Q. Weng, S.Z. Hong, L.S. Duan and Z.H. Li: Acta Botanica Boreali-Occidentalia Sinica Vol. 32 (2011), p. 95.

[8] L. Guo, Z.X. Cai, B.B. Zhang, J.L. Xu, H.F. Song and R.J. Ma: journal of Plant Nutrition and Fertilizer Vol. 19 (2013), p. 1751.

[9] S.C. Liu, L.T. Xiao, B.H. Liao, K.Q. Weng and M.F. Hu: Journal of Agro-Environment Science Vol. 25 (2006), p. 592.

[10] Y.X. Huang, B.H. Liao, L.T. Xiao, S.C. Liu and Z.K. Wang: Environmental Science Vol. 27 (2006), p. 1398.

[11] W. Lin, J. Li and S.Z Cai: Guangdong Agricultural Sciences Vol. 40 (2013), p. 39.

[12] Z.B. Hao, J. Chang and Z. Xu: Plant Physiology Experiment (Harbin Institute of Technology Press, China 2004). 